\title{
Sampling Tissue for DNAAnalysis of Trees: Trunk Cambium as an Alternative to Canopy Leaves
}

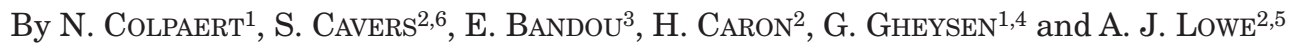

(Received 31 $1^{\text {th }}$ May 2005)

\begin{abstract}
The number of studies of tropical tree species that use molecular tools is increasing, most of which collect leaf tissue for genomic DNA extraction. In tropical trees the canopy is not only frequently inaccessible, but also, once reached, the leaf tissue is often heavily defended against herbivory by high concentrations of anti-predation compounds, which may inhibit downstream applications, particularly PCR. Cambium tissue, accessed directly from the tree trunk at ground level, offers a readily accessible resource that is less hampered by the presence of defensive chemicals than leaf tissue. Here we describe a simple method for obtaining tissue from the cambial zone for DNA extraction and test the applicability of the method in a range of tropical tree species. The method was used successfully to extract DNA from 11 species in nine families. A subset of the DNA extracts was tested in more detail and proved to be highly suitable for AFLP analysis.
\end{abstract}

Key words: DNA extraction, trees, tropical, cambium, AFLP, sample preservation.

\section{Introduction}

Tropical tree populations are increasingly being studied using molecular methods. Such studies require fresh or, more commonly given the often remote field sites, dried tissue samples for DNA extraction (SCHIERENBECK, 1994). In addition, the increasingly ambitious scale of population genetic analyses of tropical tree species means that samples are frequently required in substantial numbers.

The most common tissue sampled for genetic studies of tree populations has been leaf material. However, both collection and use of tropical tree leaf samples for molecular analysis are problematic. Firstly, tropical tree species commonly reach heights of greater than 40 metres and leaf tissue is inaccessible. Sampling of tropical tree populations has been conducted using climbing equipment (DICK, 2001) or employing tree climbers (LowE et al., 2003), but this is time consuming, labour

1) Institute for Plant Biotechnology for Developing Countries (IPBO), Ghent University, KL Ledeganckstraat 35, B-9000, Ghent, Belgium.

2) Centre for Ecology and Hydrology-Edinburgh, Bush Estate, Penicuik, Midlothian EH26 0QB, Scotland, UK.

$\left.{ }^{3}\right)$ Institut National de la Recherche Agronomique, UMR BIOGECO, 69 Route d'Arcachon, 33612 Cestas cedex, France.

4) Department of Molecular Biotechnology, Ghent University, Coupure links 653, B-9000, Ghent, Belgium.

${ }^{5}$ ) School of Life Sciences, University of Queensland, St Lucia, Brisbane, Queensland 4170, Australia.

6) To whom correspondence should be addressed: email: scav@ceh.ac.uk intensive and relatively hazardous. In addition the damage caused to the trees by the spikes used for climbing can be extensive ( $\mathrm{G}$. HERNANDEZ, pers comm.) and, although the potential effects are un-evaluated, there may be long term consequences for the individuals sampled. Secondly, tropical tree leaf tissue is subject to high rates of herbivory and infection (COLEY and BARONE, 1996) and consequently is frequently heavily defended through high concentrations of anti-predation agents including alkaloids, cyanide, polyphenols and terpenes (TURNER, 2001). Such compounds may all inhibit downstream PCR applications. Furthermore, although it is usually recommended that young leaves be sampled for successful DNA extraction, in tropical species young tissue is commonly more heavily protected against herbivory than older leaves, with higher concentrations of tannins and other polyphenols (COLEY, 1983; TURNER, 1995). Finally, leaf material frequently contains microorganisms and small insects which are not always visible. By sampling cambium tissue contamination of target DNA by foreign DNA can be avoided.

Here we describe an efficient technique for sampling tissue suitable for traditional DNA extraction procedures that accesses a resource at ground level. The method was tested on a range of tropical tree species of which 6 were tested in more detail by spectrophotometric analysis and reproducibility in AFLP analysis.

\section{Methods}

The procedure for sampling of cambial zone tissue used an ethanol-cleaned $1 \mathrm{~cm}$ diameter leather punch (Fig 1.), hammered into the bark of the target tree until stopped by the wood. The resultant plug of bark was removed with the cambial zone found on the inner surface. A very thin disc of tissue was sliced off using a clean scalpel, which was continually sterilised using ethanol between trees. The bark plug was replaced in the tree trunk and hammered tight. The $1 \mathrm{~cm}$ disc of cambium tissue was then preserved either by placing directly on silica gel in an 'O'-ring sealed $1.5 \mathrm{ml}$ screwcap plastic tube (Anachem Ltd.) or by suspension in a $1.5 \mathrm{ml}$ plastic tube containing transport buffer consist-

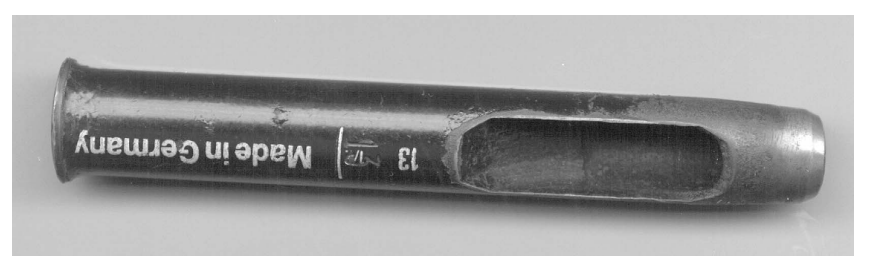

Figure 1. - Leather punch used for removing bark plug from tree trunk, from which cambium tissue can be sliced. 
ing of $70: 30$ absolute ethanol: 2X CTAB buffer $(100 \mathrm{mM}$ Trizma base, $1.4 \mathrm{mM} \mathrm{NaCl}, 20 \mathrm{mM}$ Ethylenediaminetetra-acetic Acid (EDTA), 2\% Cetyltrimethylammonium bromide (CTAB), 1-4\% Polyvinylpyrrolidone (PVP)-40 (4\% was used if species were expected to contain high quantities of polyphenolic compounds), 0.1-0.3\% ascorbic acid, $0.2 \%$ DTT (or $\beta$-mercaptoethanol $0.3 \%$ )).

For all species, Brosimum guianense, Carapa guianensis, Ceiba pentandra, Eschweilera costaricensis, Goethalsia meiantha, Laetia procera, Lecythis ampla, Maranthes panamensis, Swietenia macrophylla, Tetragastris panamensis and Vochysia ferruginea, leaf material as well as cambium tissue was taken from 3 individual trees and was preserved on silica gel.

The silica-dried cambium discs were ground to a fine powder using purpose-built racks and tubes and tungsten beads (Qiagen) and a Retsch MM300 mill set at 30 $\mathrm{Hz}$. Grinding was carried out in $30 \mathrm{sec}$. bursts, until tissue was finely powdered (usually between $30 \mathrm{sec}$. and 2 min). The buffer-preserved discs were first frozen in liquid nitrogen and then ground to a powder using a mortar and pestle.

From the ground tissue, $15 \mathrm{mg}$ was taken to perform DNA-extraction. Several DNA extraction methods were used including a commercial kit (Qiagen) but, because of higher yields, preference was given to the CTAB method (Doyle and Doyle, 1987; HARRIS, 1995; Gillies et al., 1997). For the 6 species analysed in more detail a modified CTAB was used as follows: to $700 \mu \mathrm{l}$ of standard extraction buffer (100 mM Tris-Cl pH 8, 2\% CTAB, 2\% PVP (40), $1.4 \mathrm{M} \mathrm{NaCl}, 20 \mathrm{mM}$ EDTA) $7 \mu \mathrm{l}$ proteinaseK (10 mg/ml), $140 \mu \mathrm{l} 10 \%$ SDS, $1 \%$ L-ascorbic acid (PATERsON et al., 1993) and $0.2 \% \quad \beta$-mercaptoethanol were added just before use. Samples were mixed thoroughly by vortexing and placed in a $65^{\circ} \mathrm{C}$ water-bath for 1 hour with periodic mixing. Samples were treated with $6 \mu \mathrm{l}$ RNAse $(10 \mathrm{mg} / \mathrm{ml})$ for 10 minutes at $37^{\circ} \mathrm{C}$, then $600 \mu \mathrm{l}$ chloroform/isoamylalcohol 24:1 (CIAA) was added. The tubes were inverted and centrifuged for 10 minutes at max speed (14,000 rpm). After addition of $140 \mu \mathrm{l} 10 \%$ $\mathrm{CTAB}$ and $280 \mu \mathrm{l} 5 \mathrm{M} \mathrm{NaCl}$ to the upper phase 2 extractions with CIAA were performed and precipitation was carried out with 1 volume of isopropanol. An additional step for removal of polysaccharides was performed by sodium acetate precipitation. Pellets were dissolved in $200 \mu \mathrm{l} 0.1 \mathrm{M}$ sodium acetate and $20 \mu \mathrm{l} 96 \%$ ethanol. The tubes were placed on ice for 10 minutes and centrifuged for 5 minutes at max speed and $4^{\circ} \mathrm{C}$. Supernatant was transferred to another tube and 1/10 volume $3 \mathrm{M}$ sodium acetate and 2 volumes of $96 \%$ ethanol were added. After an overnight precipitation at $-20^{\circ} \mathrm{C}$ the pellet was

Table 1. - Comparison between leaf and cambium material purity by spectrophotometric analysis. In all cases, a - cambium, b - leaf. D1-D3: Ceiba pentandra; E1-E3: Maranthes panamensis; F1-F3: Eschweilera costaricensis; G1-G3: Lecythis ampla, H1-H3: Goethalsia meiantha and I1-I3: Laetia procera.

\begin{tabular}{|c|c|c|c|}
\hline & $260 \mathrm{~nm}$ & $280 \mathrm{~nm}$ & $260 / 280$ \\
\hline D1a & 0.136 & 0.058 & 2.34 \\
\hline $\mathrm{D} 1 \mathrm{~b}$ & 0.723 & 0.433 & 1.67 \\
\hline $\mathrm{D} 2 \mathrm{a}$ & 0.071 & 0.041 & 1.7 \\
\hline $\mathrm{D} 2 \mathrm{~b}$ & 0.201 & 0.129 & 1.56 \\
\hline D3a & 0.24 & 0.139 & 1.72 \\
\hline D3b & 0.098 & 0.052 & 1.9 \\
\hline E1a & 0.091 & 0.061 & 1.5 \\
\hline E1b & 0.04 & 0.039 & 1.03 \\
\hline $\mathrm{E} 2 \mathrm{a}$ & 0.101 & 0.052 & 1.95 \\
\hline $\mathrm{E} 2 \mathrm{~b}$ & 0.064 & 0.03 & 2.12 \\
\hline E3a & 0.129 & 0.086 & 1.49 \\
\hline $\mathrm{E} 3 \mathrm{~b}$ & 0.109 & 0.059 & 1.85 \\
\hline F1a & $\mathrm{x}$ & $\mathrm{x}$ & $x$ \\
\hline $\mathrm{F} 1 \mathrm{~b}$ & 0.857 & 0.471 & 1.82 \\
\hline $\mathrm{F} 2 \mathrm{a}$ & 0.485 & 0.266 & 1.82 \\
\hline $\mathrm{F} 2 \mathrm{~b}$ & 0.223 & 0.132 & 1.7 \\
\hline $\mathrm{F} 3 \mathrm{a}$ & 0.123 & 0.04 & 3.05 \\
\hline $\mathrm{F} 3 \mathrm{~b}$ & 0.274 & 0.153 & 1.79 \\
\hline G1a & 0.261 & 0.15 & 1.74 \\
\hline G1b & 0.085 & 0.058 & 1.45 \\
\hline $\mathrm{G} 2 \mathrm{a}$ & 0.117 & 0.09 & 1.3 \\
\hline $\mathrm{G} 2 \mathrm{~b}$ & 0.453 & 0.275 & 1.65 \\
\hline G3a & 0.457 & 0.282 & 1.62 \\
\hline G3b & 0.519 & 0.299 & 1.75 \\
\hline $\mathrm{H} 1 \mathrm{a}$ & 0.133 & 0.081 & 1.64 \\
\hline $\mathrm{H} 1 \mathrm{~b}$ & 0.365 & 0.193 & 1.89 \\
\hline $\mathrm{H} 2 \mathrm{a}$ & $x$ & $x$ & $x$ \\
\hline $\mathrm{H} 2 \mathrm{~b}$ & 0.326 & 0.092 & 3.54 \\
\hline $\mathrm{H} 3 \mathrm{a}$ & 0.094 & 0.05 & 1.87 \\
\hline $\mathrm{H} 3 \mathrm{~b}$ & 0.075 & 0.046 & 1.63 \\
\hline $11 \mathrm{a}$ & 0.168 & 0.102 & 1.65 \\
\hline $11 b$ & 0.305 & 0.192 & 1.59 \\
\hline $12 \mathrm{a}$ & 0.325 & 0.129 & 2.53 \\
\hline $12 \mathrm{~b}$ & 0.343 & 0.163 & 2.1 \\
\hline $13 a$ & 2.007 & 1.504 & 1.33 \\
\hline $13 b$ & 0.37 & 0.231 & 1.6 \\
\hline
\end{tabular}


$\frac{\text { C.pentandra }}{\mathrm{B}} \quad \frac{\text { M.panamensis }}{\mathrm{A}} \quad \frac{\text { E.costaricensis }}{\mathrm{A}} \quad \mathrm{A} \frac{\text { L.ampla }}{\mathrm{A}} \quad \frac{\text { G.meiantha }}{\mathrm{B}} \quad \frac{\text { L.procera }}{\mathrm{A}}$

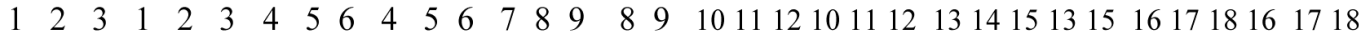

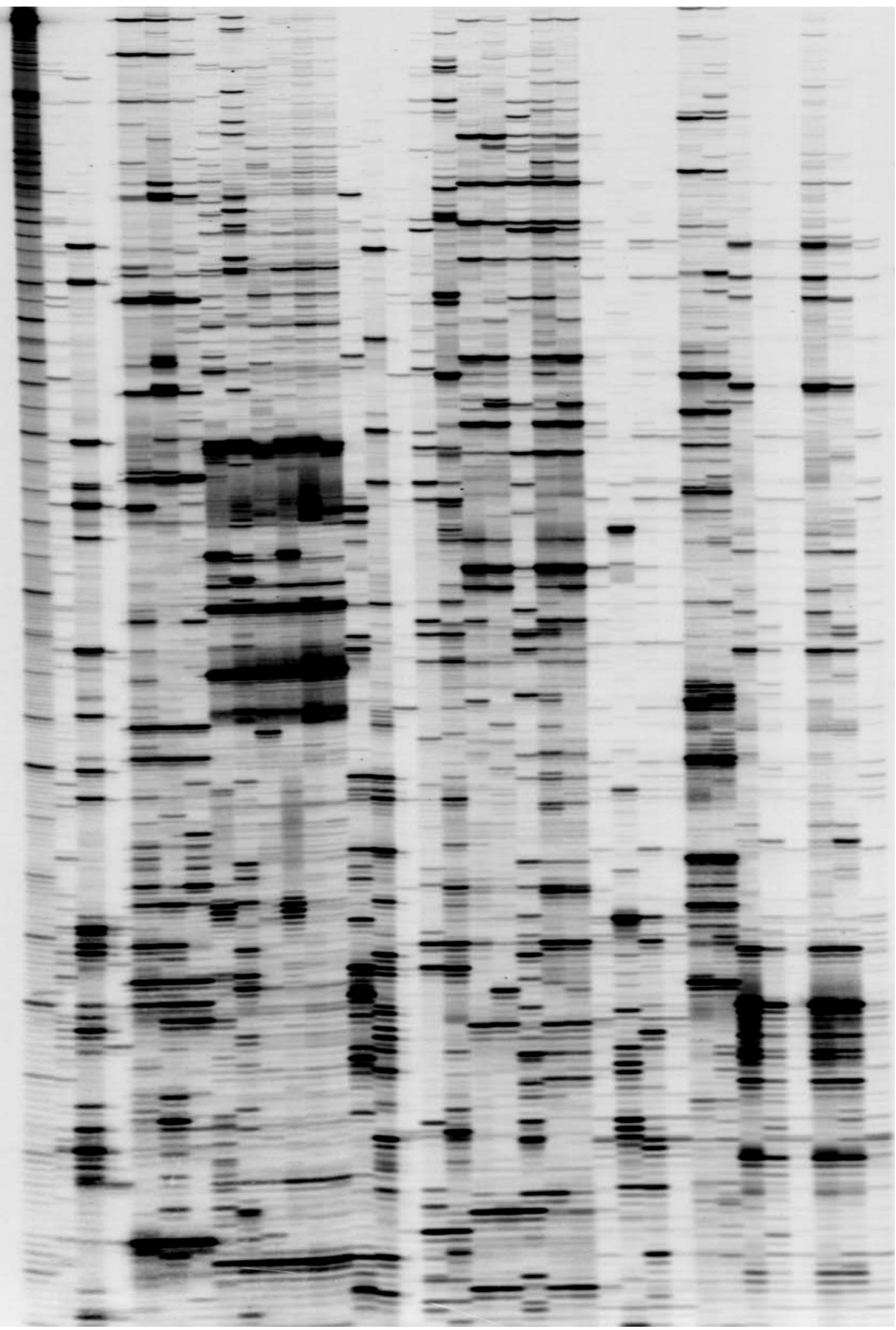

Figure 2. - AFLP print of the six species studied in detail Ceiba pentandra, Maranthes panamensis, Eschweilera costaricensis, Lecythis ampla, Goethalsia meiantha and Laetia procera with the following primer combination $E c o R I+C G / M s e I+$ ACAA on leaf material (B) and cambium tissue (A). 
washed 2 times with $70 \%$ ethanol and dissolved in $40 \mu \mathrm{l}$ water.

DNA quality was analysed by spectrophotometric analysis at $260 \mathrm{~nm}$ and $280 \mathrm{~nm}$ and templates were used for $\mathrm{AFLP}^{\circledR}$ analysis (Vos et al., 1995) with the following 2 primer combinations $E c o R I+C G / M s e I+A C A A$ and $E c o R I+C G / M s e I+A C A G$.

\section{Results}

All of the species tested yielded useful DNA extracts from cambial zone tissue samples (data not shown). Extracts from silica dried cambium tissue were compared for DNA quality with extracts prepared from silica dried leaf material by spectrophotometric analysis at $260 \mathrm{~nm}$ and $280 \mathrm{~nm}$ (SAMBRooK et al., 1989) for Ceiba pentandra, Maranthes panamensis, Eschweilera costaricensis, Lecythis ampla, Goethalsia meiantha and Laetia procera. Levels of protein contamination by $\mathrm{A}_{260} / \mathrm{A}_{280}$ ratio for all the samples is given in Table 1. Most $\mathrm{A}_{260} / \mathrm{A}_{280}$ ratios (with few exceptions) are in the range between 1.5-2.5 indicating that the level of protein contamination is low and the DNA is pure. Comparing the different extracts from the same individual we can conclude that the $\mathrm{A}_{260} / \mathrm{A}_{280}$ ratios for DNA from cambium tissue extracts are generally comparable to those of the DNA from leaf material from the same individual.

AFLP $^{\circledR}$ analysis was performed with the following 2 primer combinations EcoRI $+\mathrm{CG} / M s e \mathrm{I}+\mathrm{ACAA}$ and $E c o \mathrm{RI}+\mathrm{CG} / \mathrm{Mse}+\mathrm{ACAG}$ on DNA prepared from leaf and cambium from Ceiba pentandra, Maranthes panamensis, Eschweilera costaricensis, Lecythis ampla, Goethalsia meiantha and Laetia procera (Fig. 2). Extracts from leaf and cambium tissue from Maranthes panamensis and Lecythis ampla show no significant difference in clarity of AFLP pattern. For Ceiba pentandra, Eschweilera costaricensis, Goethalsia meiantha and Laetia procera, AFLP amplification was more successful and patterns were clearer when cambium material was used. For these 6 species tested AFLP $^{\circledR}$ results were more reproducible when extracts of cambium tissue was used compared to leaf extracts (data not shown).

\section{Discussion}

Sampling of cambial zone tissue was a highly successful method for all of the species tested: Brosimum guianense, Carapa guianensis, Ceiba pentandra, Eschweilera costaricensis, Goethalsia meiantha, Laetia procera, Lecythis ampla, Maranthes panamensis, Swietenia macrophylla, Tetragastris panamensis and Vochysia ferruginea.

The method involves collection of a small disc of cambial tissue directly from the tree trunk followed by preservation of the disc in a stabilising transport buffer or on silica gel. DNA extraction then proceeds following commonly used protocols. The technique greatly speeds up the process of sampling of tropical trees (permitting collection of samples from up to 50 individuals per day), dramatically reduces labour and was found, in some cases, to provide superior tissue for DNA extraction compared to leaf. Even under standard CTAB extrac- tion, cambium proved to yield high quality DNA extracts (i.e. for ease of use in downstream applications), presumably because, being physically protected by the tree bark, there is reduced need for the defensive chemicals in the tissue that can hamper efforts to use leaf. In our tests, preliminary results for AFLP preamplification using Qiagen DNA extracts were poor - probably as a result of low yield. Hence, we preferred the CTAB extraction procedure for its higher yields and lower costs. However, for studies requiring automation or high throughput, or when lower yields can be tolerated (e.g. for microsatellite analysis), the Qiagen kit can also be used to extract DNA from cambium. In this case, and particularly when AFLP analysis is subsequently to be undertaken, we recommend preliminary testing prior to full scale sample processing.

A number of recommendations arise from the experience of testing the method. Firstly, it was noted during the study that it is critical for both preservative methods used, that the collector ensures there is sufficient silica gel or buffer to avoid saturation. For this reason it is recommended that a very thin slice of tissue is taken and the preserving medium is recharged at least once after collection. Buffer-preserved samples were stable when refrigerated at $-20^{\circ} \mathrm{C}$ for short periods of time (up to 2 weeks): for longer storage periods tissue was removed from the buffer and dried. Although not systematically compared, silica-drying was preferred to buffer-preservation. Often, low DNA yields were obtained from cambium tissue preserved in buffer. On silica gel, tissue was stable at room temperature for more than 4 weeks and, in addition, the light, inert, solid-gel-preserved samples proved ideal for transporting collections long distance by air.

Secondly, the method is to some degree species-dependent. Where the cambium zone tissue is hard to identify or has a spongy or porous morphology, successful sampling can be difficult. Similarly, sample grinding efficiency was found to vary between species. For several of the species tested, grinding times of up to 2 minutes were necessary to obtain the fine powder that is essential for a successful DNA extraction.

Finally, a single tissue type should be used for a study - if cambium is selected as the tissue of choice for sampling, the entire study should be conducted using cambium. It has been reported that, for AFLP analysis, different tissues may yield different patterns (DonINI et al., 1997).

For tropical tree species, cambium tissue sampling offers an efficient, low-impact collecting method and a source of good-quality tissue for DNA extraction and analysis.

\section{Acknowledgements}

This study is part of the EC funded project GENEOTROPECO, contract number ICA4-CT-2001-10101; http://thoth.nbu.ac.uk/geneo. Samples were collected in Costa Rica, Brazil and French Guiana by researchers at CATIE, INRA and INPA respectively. Finally, we thank two anonymous referees for helpful comments on the manuscript. 


\section{References}

Coley, P. D. and J. A. BArone (1996): Herbivory and plant defenses in tropical forests. Annual Review of Ecology and Systematics. 27: 305-335.

Coley, P. D. (1983): Herbivory and defensive characteristics of tree species in a lowland tropical forest. Ecological Monographs. 53: 209-233.

Dick, C.W. (2001): Genetic rescue of remnant tropical trees by an alien pollinator. Proceedings of the Royal Society of London B. 268: 2391-2396.

Donini, P., M. L. Elias, S. M. Bougourd and R. M. D KOEBNER (1997): AFLP fingerprinting reveals pattern differences between template DNA extracted from different plant organs. Genome. 40: 521-526.

DoYLE, J. J. and J. L. DoYLE (1987): A rapid DNA isolation procedure for small amounts of fresh leaf tissue. Phytochemical Bulletin. 19: 11-15.

Gillies, A. C. M., J. P. Cornelius, A. C. Newton, C. NAvarro, M. Hernandez and J. Wilson (1997): Genetic variation in Costa Rican populations of the tropical timber species Cedrela odorata L., assessed using RAPDs. Molecular Ecology. 6: 1133-1145.

HARRIS, S. A. (1995): Systematics and randomly amplified polymorphic DNA in the genus Leucaena (Leguminosae, Mimosoidae). Plant Systematics and Evolution 197, 195-208.
Lowe, A. J., B. Jourde, P. Breyne, N. Colpaert, C. NAvarRO, J. WILSON and S. CAVERS (2003): Fine-scale genetic structure and gene flow within Costa Rican populations of mahogany (Swietenia macrophylla). Heredity. 90: 268-275.

Paterson, A. H., C. L. Brubaker and J. F. Wendel (1993): A rapid method for extraction of cotton (Gossypium spp.) genomic DNA suitable for RFLP or PCR analysis. Plant Molecular Biology Reporter 11: 122-127.

SAMBrook, J., E. F. FRITSCH and J. MARTin (1989): A laboratory manual. New York: Cold Spring Harbor Laboratory Press.

SCHIERENBECK, K. A. (1994): Modified polyethylene glycol DNA extraction procedure for silica gel - dried tropical woody plants. BioTechniques. 16: 393-394.

TURNER, I. M. (1995): Foliar defences and habitat adversity of three woody plant communities in Singapore. Asian Journal of Tropical Biology. 1, 31-35.

TURNER, I. M. (2001): The Ecology of Trees in the tropical Rain Forest Cambridge University Press, Cambridge.

Vos, P., R. Hogers, M. Bleeker, M. Reijans, T. Van De Lee, M. Hornes, A. Frijters, J. Pot, J. Peleman, M. KUIPER and M. ZABEAU (1995): AFLP: a new technique for DNA fingerprinting. Nucleic Acids Research. 23: $4407-4414$. 